\title{
Strategic management in the German brewing industry: Are there still differences between East and West ${ }^{*}$
}

\author{
Matthias Heyder, Ludwig Theuvsen**
}

Despite the reunification of Germany more than 15 years ago, substantial differences remain between the regions that once comprised the market-driven West and the socialist, centrally planned East. Although today's Eastern German economy is less competitive than the Western German economy, there are important exceptions to the rule. One exception is the food and beverage industry in which Eastern German companies have gained strong competitive positions. Did they reach this position by mimicking Western German blueprints, or did they go their own way? These questions are addressed in this paper by referring to a large-scale empirical study in the German brewing sector.

Auch mehr als 15 Jahre nach der deutschen Wiedervereinigung sind erhebliche strukturelle und wirtschaftliche Disparitäten zwischen West- und Ostdeutschland feststellbar. Obwohl die ostdeutsche Wirtschaft weniger wettbewerbsfähig ist als die westdeutsche, haben sich einzelne Wirtschaftsbereiche in den neuen Bundesländern dennoch sehr dynamisch entwickelt, z.B. das produzierende Ernährungsgewerbe. In dieser Branche haben sich ostdeutsche Unternehmen erfolgreich im Wettbewerb positioniert. Offen ist, ob sie dies im Wesentlichen durch das Kopieren erprobter westdeutscher Managementkonzepte vermochten, oder ob sie einen eigenständigen Weg beschritten haben. Diese Fragen werden unter Rückgriff auf die Ergebnisse einer Vollerhebung in der deutschen Brauwirtschaft beantwortet.

Key words: Brewing industry, Eastern Germany, food industry, strategic management, transformation processes transition

Manuscript received: 02.05.07, accepted: 21.12.07 (1 revision)

** Matthias Heyder, Ph.D.Student, Department of Agricultural Economics and Rural Development, Georg-August University Goettingen, Germany. Main research areas: Strategic management, internationalization of food and beverage industries and corporate social responsibility. Corresponding address: mheyder@uni-goettingen.de.

Ludwig Theuvsen, Prof./Dr., Department of Agricutral Economics and Rural Development, Georg-August University Goettingen, Germany. Main research areas: Strategic management, quality assurance in food and beverage industries and organisation of food supply chains. 


\section{Introduction}

In its transition from a centrally-planned socialistic to a market-driven economy, Eastern Germany is in a very special position compared to other transition countries in Central and Eastern Europe. This is because, first, the economy of the German Democratic Republic was fully absorbed by the economic system of the Federal Republic of Germany and, second, the transition process from a command to a market economy took place in a very short period of time (Clarke-Hill/Robinson 1996).

Within the CIS, Russia has been the leading country in terms of their share of the private sector in a country's economy from the very beginning of the transition period. Although the reunification of Germany took place more than 15 years ago, there are still fundamental disparities between the western and the eastern parts of the country. Macroeconomic parameters such as the unemployment rates and per capita gross national product still vary remarkably between the two regions. In general, the productivity in Eastern Germany lags behind that of Western Germany (DIW Berlin/IAB/IfW/IWH/ZEW 2003), but at the same time foreign-owned and Western German subsidiaries achieve 40 percent and 12 percent respectively higher productivity than the German average (Industrial Investment Council 2005; Günther/Gebhardt 2005).

Earlier research on the economic structure of Eastern Germany was based predominantly on the social sciences and focused mainly on the transition process and on industrial relations in particular. (Cf., for example, Breu 1996; Pohlmann/Gergs 1996; Steinhöfel 1996; Dyck 1997; Gergs 2002; Lohr 2003) Other authors, such as Günther and Gebhardt (2005), analysed the role of foreign and Western German investors in the technological renewal of Eastern Germany. Little research, however, has been carried out with regard to the strategic management of Eastern German companies. In particular, the food and beverage industries have been neglected in this context although these sectors are, compared to other sectors of the Eastern German economy, more successful when measured in terms of such factors as growth rates and market shares and, hence, could represent a benchmark for other sectors of the economy. Bearing in mind that during the first period of the reunification process the food and beverage industries in the former German Democratic Republic were anything but competitive in a market economy (Schwartau 1990), this is a remarkable result which today, more than 15 years later, indicates the value of taking a closer look at these industries in Eastern Germany.

Whether the catch-up process of the Eastern German food and beverage industries is due to the successful mimicking of Western German strategic management concepts or whether Eastern German companies have remained special in some way and differ with regard to the strategies they pursue has never been thoroughly explored. In this paper, we contribute to answering this question by analysing similarities and differences between strategic management 
in the Eastern and the Western German brewing industries. Since Steele (1992) could observe country-depending disparities with managerial implications in the European brewing sector and, furthermore, since competitive pressures in the German brewing industry have sharply increased during recent decades, the brewing sector is an attractive object for analysing strategic management issues (Niederhut-Bollmann 2006). We analyse in particular in this paper whether breweries in the two German regions perceive their enterprise and industry situation differently, whether their corporate strategies and competitive behaviour are the same or not, and whether firm performance differs between brewing companies in Eastern and Western Germany.

The analysis is based on a large-scale empirical study of the German brewing industry. After a short overview of the transition process and the structure of the food and beverage industries in Eastern Germany, the results of the study will be presented with regard to differences and similarities in the strategic management in Western and Eastern German breweries. A discussion of the implications of the empirical results concludes the paper.

\section{Development and structure of the food and beverage industries in Eastern and Western Germany}

After World War II, very different economic systems emerged in both parts of Germany. Whereas Western Germany was transformed into a social market economy, the industry in Eastern Germany was centrally planned and dominated by 270 centrally or regionally managed state-owned industrial combines (Kombinate) (Lederer 1998). Beverage, meat, bread and pastry production remained somewhat special in the German Democratic Republic since it was organized primarily by locally run Kombinate or even remained in the hands of small, often independent production units run by self-employed entrepreneurs. At the end of this period, the Eastern German brewing sector consisted of about 200 breweries with approximately 600 production sites, all satisfying only modest quality requirements (Schwartau 1990; Kahle 1991).

After the fall of the Berlin Wall in autumn 1989, it was not long before the economy of Eastern Germany was absorbed by the much larger, market-driven Western German economy. The transition from a command economy to a social market system led to a privatization process and implied the market entry of numerous foreign and Western German companies (Clarke-Hill/Robinson 1996). Schwartau (1990) found that the rate of depreciation (cumulated depreciations as a proportion of gross fixed capital) was about 58 percent in 1988. Therefore, investments in production facilities were badly needed (BMELV 2006). Accordingly, as in most transition countries after the fall of the iron curtain, a strong increase in foreign direct investments (FDI) occurred (Günther/Gebhardt 2005). Among other industries, food, beverage, and 
consumer good manufacturers in Central and Eastern Europe benefited from FDI (Marinov 2002; Günther/Gebhardt 2005).

Enterprises in the Eastern German food and beverage industries led the way in the restructuring process to a market economy after numerous investments by Western German and international enterprises (Drescher/Halm 2005). According to the Industrial Investment Council (2006), Eastern Germany has traditionally been a stronghold for the food and beverage industries, with companies covering the entire value chain. Today more than 260 international and national players are operating in the industry, and over 60 logistics centres of major food retailers are located in the region. Foreign investments by multinational corporations such as Nestlé, Danone, Coca-Cola, Cargill Food Systems and Schwan's Sales Enterprises underline the importance of Eastern Germany as a production location and distribution hub in the European food and beverage industries.

In 2005, German companies in the food industries (including tobacco manufacturing) with more than 20 employees realized a turnover of $€ 153$ billion and employed more than 500,000 people (cf. Table 1). As the comparatively high export quota (14.2 percent) shows, German food industry products face strong demand outside their domestic market due to high product quality. With more than 1,200 enterprises and about 100,000 employees (German Federal Statistical Office 2006), the food industry is one of the most important economic sectors in Eastern Germany. Unlike in many other industries, the number of enterprises and employees in the food industry parallels Eastern Germany's share of the total population, which is about 15 percent. Gergs (2002) argues that large foreign direct investments and the subsequent strong position of the food industry were caused by the deficient infrastructure after reunification and the need for short transport ways and times for perishable and transport sensitive goods.

A remarkable difference between the food industries in Eastern and Western Germany can be observed with regard to their export orientation. The export quota of the food industry in Western Germany (15.7 percent) is almost twice as high as the one in Eastern Germany where the food industry generates only about 8.5 percent of its turnover outside Germany.

The meat and dairy industries are by far the largest sub-sectors of the German food industry with a turnover of more than $€ 20$ billion each. Following the producers of bakery goods, the beverage industry is the fourth largest sub-sector of the food industry. In this domain, the brewing industry is the leader, followed by the refreshments sector (German Federal Statistical Office 2006). Taken separately, the brewing industry is Germany's fifth largest sub-sector of the food and beverage industry with a turnover of about $€ 8.4$ billion and had about 33,400 employees in companies with 10 or more employees in 2004 (BMVEL 2005). Furthermore, more than 100,000 people are currently employed in 
upstream and about 50,000 people in downstream sectors of the brewing industry (German Brewers Association 2006b).

Table 1. Structure of the food and beverage industries in Germany, 2005 (enterprises with more than 20 employees; including tobacco manufacturing):

\begin{tabular}{|l|c|c|c|}
\hline $\begin{array}{l}\text { Food and beverage } \\
\text { industries }\end{array}$ & Germany & Western Germany & $\begin{array}{c}\text { Eastern Germany } \\
\text { (including Berlin) }\end{array}$ \\
\hline Companies & 5,956 & $4,740(79.6 \%)$ & $1,216(20.4 \%)$ \\
\hline Employees & 532,945 & $432,445(81.1 \%)$ & $100,500(18.9 \%)$ \\
\hline Turnover $(€ 1,000)$ & $152,890,971$ & $120,090,987(78.6 \%)$ & $32,799,984(21.4 \%)$ \\
\hline Export quota $(\%)$ & 14.2 & 15.7 & 8.5 \\
\hline
\end{tabular}

Source: German Federal Statistical Office 2006

\section{Structure and trends in the Eastern and Western German brewing sectors}

In 2005, there were 1,274 breweries in Germany which produced 108,249 million hectolitres (hl) of beer (German Brewers' Association 2006a). The structure of the German brewing industry is unique since Germany has by far the largest number of breweries in the world. Of all the breweries in the European Union, 75 percent are located in Germany. Therefore, the average size of German breweries is comparatively small. In 2004, the average production of beer per brewery and year was $83,350 \mathrm{hl}$ in Germany as a whole and only $35,800 \mathrm{hl}$ in Bavaria and 43,400 hl in Baden-Württemberg. These numbers are far below the average figures from production sites in other European countries such as the UK $(957,650 \mathrm{hl})$ and the Netherlands $(1,702,000 \mathrm{hl})$ (German Brewers' Association 2006b, 2006c).

Currently, radical structural changes are occurring in the German brewing sector (Table2). However, this is not a new development. The brewers in Germany have been facing increased competitive pressures for about twenty years. Changing consumer behaviour has resulted in a shrinking beer market volume; the constantly falling per capita beer consumption is now about 115 litres per year (Niederhut-Bollmann 2006). International brewing groups have entered the German market and have been pursuing aggressive marketing and pricing strategies (Ebneth 2006). Furthermore, so-called hybrid consumers tend to show multi-optional buying behaviour. On the one hand, consumers are distinctly price-oriented; on the other hand, they also show narcissistic or hedonistic behaviour with a desire for luxury goods (Kunert 2006). With regard to the consumption of beer, the consumption trend goes to cheap beer as well as to regional and national premium brands. Due to overcapacities and the trend towards cheap beer, price and competitive pressures have been growing constantly (Niederhut-Bollmann 2006; German Brewers' Association 2006a). 
Competitive pressures result in severe structural changes in the industry. Whereas the total number of breweries in Germany has not significantly changed over the years, Table 2 clearly shows the erosion of the middle segment and a trend towards very large brewing groups, on the one hand, and microbreweries on the other. Newly founded microbreweries are, in most cases, restaurants with integrated breweries, and the beer is sold predominantly in the related restaurants. This trend very much parallels similar developments in the US beer market since the 1980s (Bastian et al. 1999; Carroll/Swaminathan 2000; Anonymous 2007). Its consequence has been a concentration process in the German brewing sector. The CR5, i.e., the aggregated market share of the five largest breweries, was about 52 percent in the year 2004, whereas it was only about 28 percent in the year 1998 . The brewing sector has slowly but continually developed towards being a wide oligopoly dominated by several national brewing groups and local subsidiaries of international brewing groups with a high competitive intensity (Niederhut-Bollmann 2006).

Table 2. Structures in the German brewing sector with regard to output size:

\begin{tabular}{|l|c|c|c|}
\hline \multirow{2}{*}{ Company size by annual production volume } & \multicolumn{2}{|c|}{ Number of companies } & \multirow{2}{*}{$\begin{array}{c}\text { Change } \\
\text { (in \%) }\end{array}$} \\
\cline { 2 - 3 } & 1995 & 2004 & \\
\hline Microbreweries (<5,000 hl p.a.) & 643 & 796 & +23.8 \\
\hline Small breweries (5,000-50,000 hl p.a.) & 393 & 280 & -28.8 \\
\hline Medium-sized breweries (50,000-200,000 hl p.a.) & 136 & 116 & -14.7 \\
\hline Large breweries (200,000-1,000,000 hl p.a.) & 71 & 53 & -25.4 \\
\hline Brewing groups (>1,000,000 hl p.a.) & 29 & 29 & +-0 \\
\hline Total & 1,282 & 1,274 & -0.6 \\
\hline
\end{tabular}

Source: German Brewers Association 2006

The large majority ( 86 percent) of the breweries are located in the western part of Germany; about 14 percent of the brewing facilities are located in Eastern Germany (German Brewers' Association 2006a). Western Germany produces 79 percent of the total beer output in Germany; Eastern Germany produces 21 percent. This means that the average output of Eastern German breweries is $128,488 \mathrm{hl}$ and, thus, markedly larger than the one achieved in the Western part $(75,953 \mathrm{hl})$. Furthermore, the share of production in Eastern Germany is larger than its share of the total population (15 percent), which exemplifies the great importance and competitiveness of the food and beverage industries in Eastern Germany. 
Table 3. Structures in the German brewing sector with regard to economic parameters:

\begin{tabular}{|l|c|c|c|}
\hline \multicolumn{1}{|c|}{ Breweries } & Germany & $\begin{array}{c}\text { Western } \\
\text { Germany }\end{array}$ & $\begin{array}{c}\text { Eastern } \\
\text { Germany (incl. } \\
\text { Berlin) }\end{array}$ \\
\hline Brewing facilities & 1,274 & 1,102 & 172 \\
\hline $\begin{array}{l}\text { Breweries with more than } 20 \\
\text { employees }\end{array}$ & 315 & 272 & 43 \\
\hline Output (in mill. hl) & 105.8 & 83.7 & 22.1 \\
\hline Average output per facility in hl & 83,049 & 75,953 & 128,488 \\
\hline Employees * & 32,466 & 27,979 & 4,484 \\
\hline Turnover (mill. $€$ ) & 8,201 & 6,949 & 1,251 \\
\hline Domestic turnover (mill. $€)^{*}$ & 7,645 & 6,407 & 1,239 \\
\hline Turnover abroad (mill. $€)^{*}$ & 555 & 542 & 13 \\
\hline Export quota (turnover)* & 6.8 & 7.8 & 1.0 \\
\hline
\end{tabular}

* breweries with more than 20 employees

Sources: German Federal Statistical Office 2006; German Brewers Association 2005; Kunert 2006

With regard to export as a percentage of the turnover, Table 3 shows that, similar to the case of the food industry as a whole, the export orientation of Western German breweries is significantly greater than that of the Eastern German ones. Although Ebbertz (1992) stressed that for some (Western) German breweries (for instance, Brauerei Beck \& Co. and Holsten-Brauerei AG) exporting has always played an important role, and there had been an increase in exports during recent years. The export quota (in percentage of beer output) rose from 8.4 percent $(9.46$ mill. hl) in 1999 to 13.4 percent in 2004 (14.55 mill. hl). In contrast, the export quota of the Eastern German breweries is only 1.0 percent (German Federal Statistical Office 2006) and, therefore, exports are a distribution channel of limited importance. The beer imports have risen from only 2.5 percent of the domestic consumption ( 3.05 mill. hl) in 1999 to 4.6 percent (4.39 mill. hl) in 2004 (German Brewers' Association 2006a). Only rising beer exports could stop the long-term decline in the total beer output, but the problem of overcapacities in the market that has resulted from shrinking domestic consumption is still prevalent (Niederhut-Bollmann 2006).

A further structural change and source of growing competitive pressures in the German brewing industry is the market entry of new competitors, especially major international brewing groups such as Heineken, Carlsberg, and Inbev (Ebneth 2006; Ebneth/Theuvsen 2007). Whereas these international brewing groups' internationalization strategies with exports to Germany and international licensing had largely failed in the past, acquisitions of domestic breweries turned out to be a much easier market-entry strategy. The internationalization strategies of foreign competitors as well as mergers and acquisitions of national market leaders have strongly contributed to the ongoing consolidation process in the 
German brewing sector (Kunert 2006; Niederhut-Bollmann 2006). Eastern Germany appeared an attractive place for investments mainly by Western German but also global brewing groups, and a lot of breweries in Eastern Germany have been targets of Western German and foreign investors. All in all, the percentage of breweries that have been taken over in Eastern Germany is higher than in Western Germany. Moreover, the remaining independent breweries in Eastern Germany are potential future targets for investors. Some mergers and acquisitions that have substantially changed the Eastern German brewing landscape are summarized in Table 4.

Table 4. Important mergers and acquisitions in the Eastern German brewing sector:

\begin{tabular}{|l|l|}
\hline \multicolumn{1}{|c|}{ Target } & \multicolumn{1}{c|}{ Acquirer } \\
\hline Ur-Krostitzer, 04509 Krostitz & Radeberger Group/Oetker (D) (1990) \\
\hline Hasseröder, 38855 Wernigerode & $\begin{array}{l}\text { Gilde Brauerei AG (1990) } \\
\text { Inbev (B) (2001) }\end{array}$ \\
\hline Radeberger Exportbierbrauerei, 01454 Radeberg & Radeberger Group/Oetker (D) \\
\hline $\begin{array}{l}\text { Leipziger Brauhaus zu Reudnitz (Reudnitzer, } \\
\text { Sternburg), 04317 Leipzig }\end{array}$ & $\begin{array}{l}\text { Radeberger Group/Oetker (D) } \\
\text { (2005/2006) }\end{array}$ \\
\hline Köstritzer, 07586 Bad Köstritz & Bitburger Th. Simon (D) (04/1991) \\
\hline Wernesgrüner, 08237 Wernesgrün & Bitburger Th. Simon (D) (1994) \\
\hline Sternquell, 08523 Plauen & Kulmbacher Gruppe/BHI (D) (10/1990) \\
\hline Freiberger Brauhaus, 09584 Freiberg & $\begin{array}{l}\text { Eichbaum Brauereien AG (D) (1990) } \\
\text { Radeberger Group/Oetker (D) (2006) }\end{array}$ \\
\hline Altenburger Bier, 04600 Altenburg & Leikeim Group (D) (1991) \\
\hline Lübzer Pils, 19386 Lübz & $\begin{array}{l}\text { Holsten AG (D) (1991) } \\
\text { Carlsberg (DK) (2004) }\end{array}$ \\
\hline Preußen Pils, 16928 Pritzwalk & Oettinger (D) (2006) \\
\hline Hanseatisches Brauhaus Rostock, 18057 Rostock & $\begin{array}{l}\text { Brauerei Beck GmbH\& Co. KG (1991) } \\
\text { Brau \& Brunnen (2003) } \\
\text { Radeberger Group/Oetker (D) (2004) }\end{array}$ \\
\hline
\end{tabular}

Source: Websites of breweries/CaribouVerlag 2006

In the following section, the findings of an empirical study that highlights differences as well as similarities in strategic management in Eastern and Western German breweries are presented. Günther and Gebhardt (2005) hypothesized that enterprises in Eastern and Western Germany differ in terms of research and development, organizational structure, and market orientation. Whether this hypothesis is still supported by empirical data is an open question. 


\section{Empirical Research}

\subsection{Theoretical framework}

The empirical research in this study was guided by a framework which employs ideas from several theoretical strands, mainly industrial organization, organization theory, and strategy research.

The structure-conduct-performance paradigm (Mason 1949; Bain 1968) popular in the literature on industrial organization takes into account the external determinants of strategy and can be regarded as the basic theoretical framework not only of modern competitive theory but also of microeconomic strategy research (Bühler/Jaeger 2002). Within industrial organization research, two development directions can be distinguished. One theoretical strand assumes a passive adaptive behaviour of firms supposing a one-sided causality. This research direction views the conduct and the resulting performance or success of an enterprise as determined by the structure of the industry (Hay/Morris 1979; Böbel 1984). The competing behaviourist approach also takes into account firm behaviour and the interdependences between market structure and market behaviour. Taking into account the competitive strategies of market players allows intra-industrial analyses (Scherer 1985; Jaquemin 1986). In our research we employ the second approach.

The empirical research in this study was furthermore guided by an advanced contingency-theoretical framework. In general, the contingency approach assumes that there is not just one best form of organization. Instead, the performance of an organization is considered dependent on the quality of the fit between contingency factors and the configuration of the organization (Van de Ven/Drazin 1985; Donaldson 2001; Ebers 2004). Advanced versions of the contingency approach concede that decision makers can influence the configuration of the organization and that there is no deterministic impact of the environment on an organization (Kieser 2006). In this context, we refer to the concept of strategic choice which normally is a three-stage procedure (Child 1972):

1. An evaluation of the environment the organization is in.

2. A configuration of external strategies to influence the market environment and improve the market efficiency.

3. A configuration of internal strategies to increase the efficiency of the organization.

Contingency theory and its central concept of fit have also gained much relevance in strategy research (Venkatraman 1989). Analogous to Chandler's (1962) "structure follows strategy" hypothesis, it is widely accepted that "strategy follows situation" (Fombrun/Wally 1989) or - put differently - that the situation determines a firm's strategy and that the quality of the fit determines 
firm performance. Nevertheless, firm strategies may also be used to actively influence the environment (Pfeffer/Salancik 1978; Pennings 1981).

Figure 1. Theoretical framework:

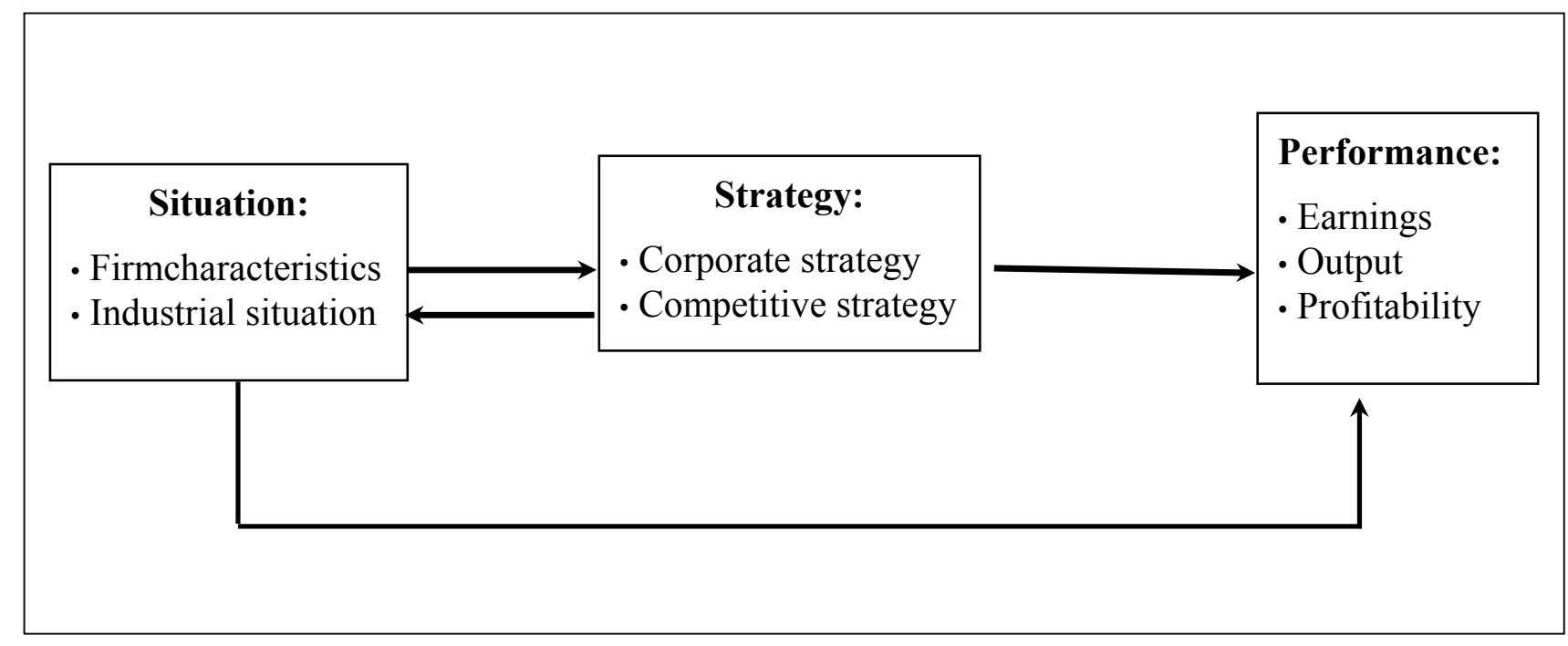

Source: modified after Niederhut-Bollmann 2006

Taking these insights into account (cf. our theoretical framework outlined in Figure 1), the situation within an industry as well as the characteristics of a firm (such as age, size, and availability of financial and managerial resources) determine firm strategies; but, vice versa, firm strategies also influence the competitive situation within an industry, for instance, price pressure and the innovation rate. The performance of enterprises is determined by the fit between the firm strategy, on the one hand, and the situation, on the other. Furthermore, the situation, e.g., legislation, also directly influences firm performance, regardless which strategy a firm pursues and how well this strategy is implemented. Subsequently, we will outline the building blocks of the theoretical framework in more detail in the following.

\section{Situation}

The situation consists of the aforementioned external and internal determinants of the structure and strategy of a firm. Parameters representing the internal situation of a brewery include the legal form, ownership structure, number of employees and, of course, brewery size. The external dimension of the situation is represented mainly by factors characterising the brewing sector, e.g., all the factors influencing competitive pressures.

\section{Strategies}

Strategies are long-term plans that guide a firm's day-to-day operational decisions and have a major impact on the firm's performance and the future firm development (Frese 1987). This study concentrates on the external dimension of strategies. In accordance with this precondition, a strategy determines the 
market-orientation of a company, its competitive behaviour, and the allocation of resources to reach the firm's objectives. In the literature on management, two main strategy levels are distinguished (Hofer/Schendel 1978; Barney 2001):

- Corporate strategy: On the corporate level, the most important strategic decision is the choice of what the company produces and for whom (product-market combinations). Furthermore, decisions concerning distribution channels, internationalization, growth, and diversification are part of the corporate strategy.

- Competitive strategy: On the level of strategic business units, decisions on a firm's competitive behaviour have to be made. Porter (1985) popularized the distinction between cost leadership, differentiation and niche strategies and showed possible ways to gain competitive advantages on a business unit level.

\section{Performance}

Indicators frequently used for analysing the performance of a firm are output and financial criteria (for instance, Lawrence/Lorsch 1967). In our study, the success of breweries is measured through output and productivity as well as profitability meters.

\subsection{Methodology and sample}

The theoretical framework developed served as a basis for a large-scale empirical study. All theoretical constructs were operationalized in a questionnaire which comprised a total of 211 situational, strategic, performance, and moderating variables. These show different scaling. Where the respondents were asked to evaluate given statements, five-point Likert scales were used. The performance variables were surveyed in two steps. First, the breweries were asked to disclose information about percentage changes in output quantities, turnover, earnings and return on investments (ROI) over the last three years. Then they were asked to self-evaluate their productivity, profitability, and financial power in comparison with industry averages.

In a pre-test respondents had no difficulties with the questionnaire. Only one question-concerning exit strategies-was deleted since it was considered too sensitive. SPSS 12.0 for Windows was used for the data analysis.

In 2005, 1,260 German breweries were surveyed using a standardised written questionnaire. The sample is slightly smaller than the number of breweries $(1,274)$ published by the German Brewer Association due to factors such as some recent bankruptcies in the industry. 281 analysable questionnaires were returned. This represents a response rate of about 22 percent of the sample, including microbreweries; the response was even higher-about 40 percentamong the group of breweries with an annual output of more than 5,000 hl. 


\subsection{Empirical findings}

\subsubsection{Situation - Industrial situation and characteristics of the firms}

Competitive pressure in the brewing industry has increased in recent years (Niederhut-Bollmann 2006). We also found that most breweries perceive competitive pressure on their main selling markets as high with no significant differences between Western and Eastern Germany. But a look at the respondents' perceived competitiveness of their own enterprises reveals a striking difference (cf. Table 5). Whereas most Eastern German brewers consider themselves weaker than their main competitors, Western German brewers show distinctly higher self-esteem and regard themselves as being at least as strong as or even stronger than their main competitors.

Table 5. German breweries' perception of competitive pressures and their own competitiveness:

\begin{tabular}{|c|c|c|c|c|c|c|c|c|}
\hline & \multicolumn{4}{|c|}{ West } & \multicolumn{4}{|c|}{ East } \\
\hline & \multicolumn{2}{|c|}{$\begin{array}{c}\text { Competitive } \\
\text { pressure } \\
(\mu=4.10 ; \sigma= \\
0.839)\end{array}$} & \multicolumn{2}{|c|}{$\begin{array}{l}\text { Competitiveness } \\
(\mu=3.07 ; \sigma=0.895)\end{array}$} & \multicolumn{2}{|c|}{$\begin{array}{c}\text { Competitive } \\
\text { pressure } \\
(\mu=4.00 ; \sigma=0.981)\end{array}$} & \multicolumn{2}{|c|}{$\begin{array}{c}\text { Competitivenes } \\
\mathrm{s}(\mu=2.61 ; \sigma= \\
0.994)\end{array}$} \\
\hline & n & $\%$ & n & $\%$ & $\mathbf{N}$ & $\%$ & n & $\%$ \\
\hline very low (1) & 3 & $1.2 \%$ & 14 & $5.6 \%$ & 1 & $3.6 \%$ & 3 & $10.7 \%$ \\
\hline low (2) & 9 & $3.6 \%$ & 43 & $17.3 \%$ & 2 & $7.1 \%$ & 11 & $39.3 \%$ \\
\hline $\begin{array}{l}\text { neither low } \\
\text { nor high (3) }\end{array}$ & 31 & $12.4 \%$ & 109 & $44.0 \%$ & 1 & $3.6 \%$ & 9 & $32.1 \%$ \\
\hline $\operatorname{high}(4)$ & 123 & $49.4 \%$ & 76 & $30.6 \%$ & 16 & $57.1 \%$ & 4 & $14.3 \%$ \\
\hline very high (5) & 83 & $33.3 \%$ & 6 & $2.4 \%$ & 8 & $28.6 \%$ & 1 & $3.6 \%$ \\
\hline
\end{tabular}

Besides competitive pressures and firm competitiveness, the respondents were also asked how many of their competitors had recently terminated production or been taken over. The results clearly reflect the ongoing consolidation process in the industry and show distinct West-East differences. In Western Germany, 74.3 percent of the respondents saw competitors exiting the market compared to only 42.1 percent in Eastern Germany.

Concerning the threat of new competitors entering the market in their main sales areas, no differences were found between Western $(\mu=2.90 ; \sigma=0.94)$ and Eastern $(\mu=2.93 ; \sigma=0.95)$ German breweries. This imminence is rated neither low nor high in either part of Germany.

With regard to the legal form of German breweries, sole proprietorships are predominant. They are followed by private limited companies $(\mathrm{GmbH})$ and limited partnerships with private limited companies ( $\mathrm{GmbH} \& \mathrm{Co} . \mathrm{KG})$. In this respect, interesting differences can be observed between Western and Eastern Germany. The legal forms of public company (AG) and limited partnership 
$(\mathrm{KG})$ can only be found in Western Germany, while in Eastern Germany the legal forms of sole proprietorship and private limited company $(\mathrm{GmbH})$ clearly prevail. In addition, due to the differing political histories of the two regions, the share of family-owned enterprises is much lower in Eastern Germany (65.4 percent) than in Western Germany (88.6 percent).

These findings concerning legal forms and ownership are of great interest with regard to the consolidation process in the industry because most respondents from Eastern (92.6 percent) as well as Western (92.7 percent) Germany do not yet belong to brewing groups. This situation is very different from that in Central and Eastern Europe where internationalization in the brewing industries through international FDI has further developed substantially (Theuvsen/Niederhut-Bollmann 2004; Ebneth/Theuvsen 2006).

According to the theoretical framework introduced, the industrial situation influences the strategies implemented by brewers. Similarities and differences in strategic management between East and West are presented below.

\subsubsection{Strategy}

\section{Corporate Corporate Strategies}

The foci of corporate strategies in the brewing industry are the choice of product-market combinations, distribution, and internationalization strategies (Niederhut-Bollmann 2006).

The main product of breweries is beer, representing 78.4 percent of the total output in our sample. But many breweries produce non-alcoholic drinks and other refreshments, too. The share of these beverages among the breweries' total beverage output is less than 10 percent $(\sigma=16.96)$ in Eastern but almost 23 percent $(\sigma=21.12)$ in Western Germany. Regarding the product-mix of breweries (Figure 2), it is obvious that pilsner is by far the prevailing beer type in Germany but enjoys even greater importance in the East. Differing consumer preferences in various regions such as the predominance of lager and wheat beer in Bavaria explain the difference (Brunken 1990).

Due to, on the average at least, small-scale production facilities in Germany, the main sales areas for most breweries are local and regional markets. Again, the situation in the sector is more heterogeneous in Western Germany than in the Eastern part of the country. On the one hand, the percentage of breweries that deliver mainly to local markets is higher in Western than in Eastern Germany. On the other hand, about 3.5 percent of the respondents in Western Germany consider a broader region or the national market their main sales area. In contrast, the absence of a strong national brand in the Eastern German sample is striking. 
Figure 2. Product mix of breweries:

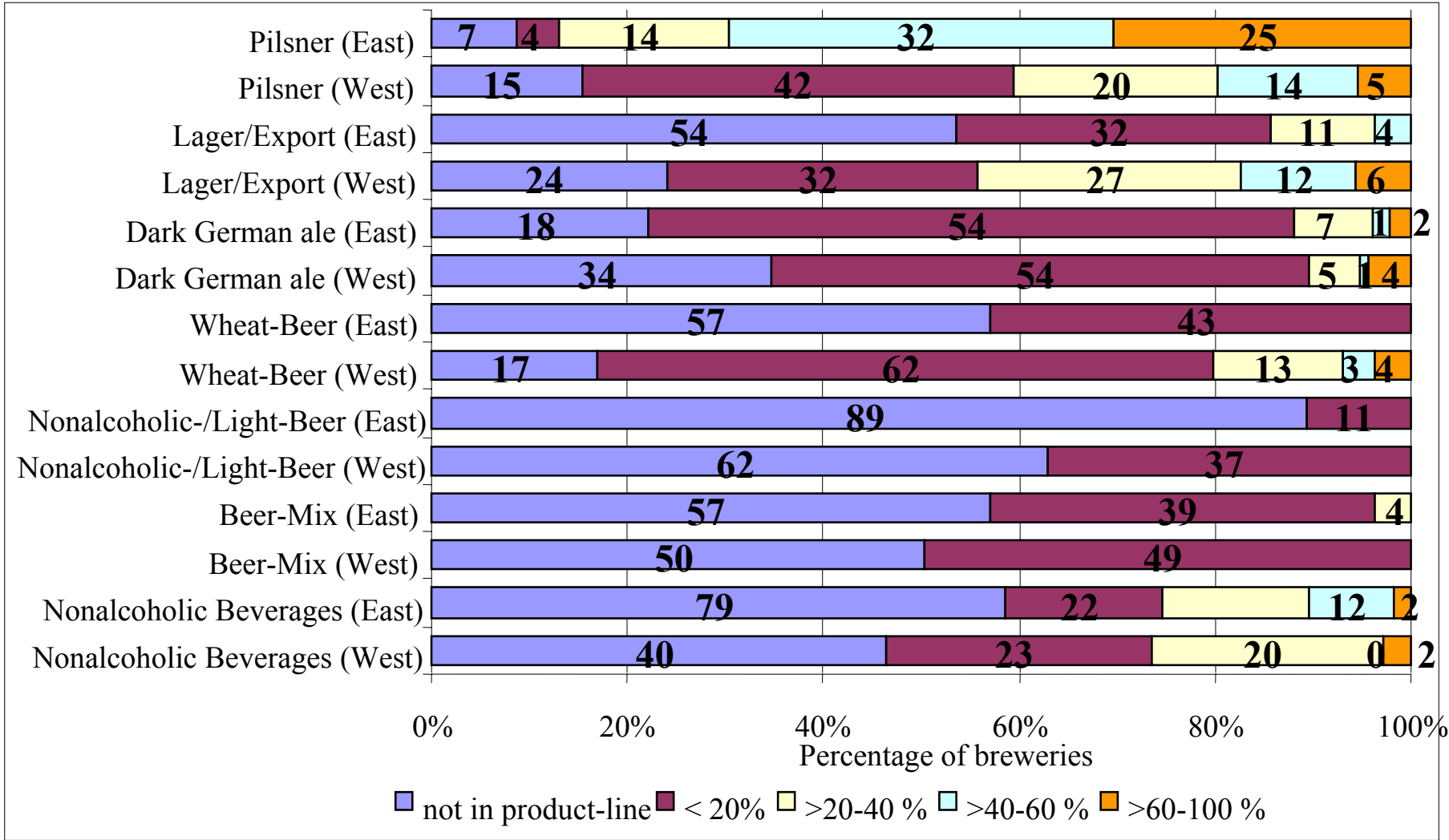

With regard to their strategic development direction, firms can choose between growth, stability, and retrenchment strategies (Wheelen/Hunger 2000). In the shrinking and highly competitive German beer market, many firms have chosen a growth strategy. Mainly larger breweries from Western Germany have acquired other breweries over the past five years because mergers and acquisitions are considered an attractive opportunity that cannot be pursued by small breweries and microbreweries due to financial restrictions.

Table 6. Main selling markets of responding breweries:

\begin{tabular}{|l|c|c|c|c|}
\hline \multirow{2}{*}{ Main selling market } & \multicolumn{2}{|c|}{ West $(\boldsymbol{\mu}=\mathbf{1 . 3 3} ; \boldsymbol{\sigma}=\mathbf{0 . 6 4})$} & \multicolumn{2}{c|}{ East $(\boldsymbol{\mu}=\mathbf{1 . 4 3} ; \boldsymbol{\sigma}=\mathbf{0 . 5 0})$} \\
\cline { 2 - 5 } & $\mathbf{n}$ & $\mathbf{\%}$ & $\mathbf{n}$ & $\mathbf{\%}$ \\
\hline local (1) & 183 & $73.2 \%$ & 16 & $57.1 \%$ \\
regional (2) & 58 & $23.2 \%$ & 12 & $42.9 \%$ \\
in a broader region & 2 & $0.8 \%$ & --- & --- \\
(3) & 7 & $2.8 \%$ & --- & --- \\
national (4) & & & \\
\hline
\end{tabular}

For the future, 35 percent of all the interviewed brewers with an output of more than $100,000 \mathrm{hl}$ per year consider buying other breweries. But only respondents from Western Germany (12.6 percent) have already implemented such plans. At 
the same time, it is worth noting that most breweries in Western Germany (71.9 percent) have not considered taking over other breweries.

Unlike other industries, very diverse distribution channels exist in the brewing sector. The choice of a distribution channel is mainly determined by the size of the brewery, the costs of alternative channels, and the market segment in which the brewery operates (Brunken 1990; Ebbertz 1992). Our findings show that breweries in Eastern and Western Germany often choose different distribution channels. The on-premise market describes distribution channels in which beer is immediately consumed at the point of sale (gastronomy, festivals, cinemas, etc.). This market has been shrinking for several years in Germany (NiederhutBollmann 2006). Gastronomy is the leading on-premise segment and more important in Eastern Germany. There, 42 percent of beer is sold through this channel, compared to only 28 percent in the western part of Germany.

With regard to off-premise sales where beer is not consumed at the point of sale, further differences are observable. In the eastern part of Germany, the share of beer sold by food retailers is twice as high as in the western part, whereby brewery-owned, home-delivery services are a Western German speciality.

Figure 3. Distribution channels of German breweries:

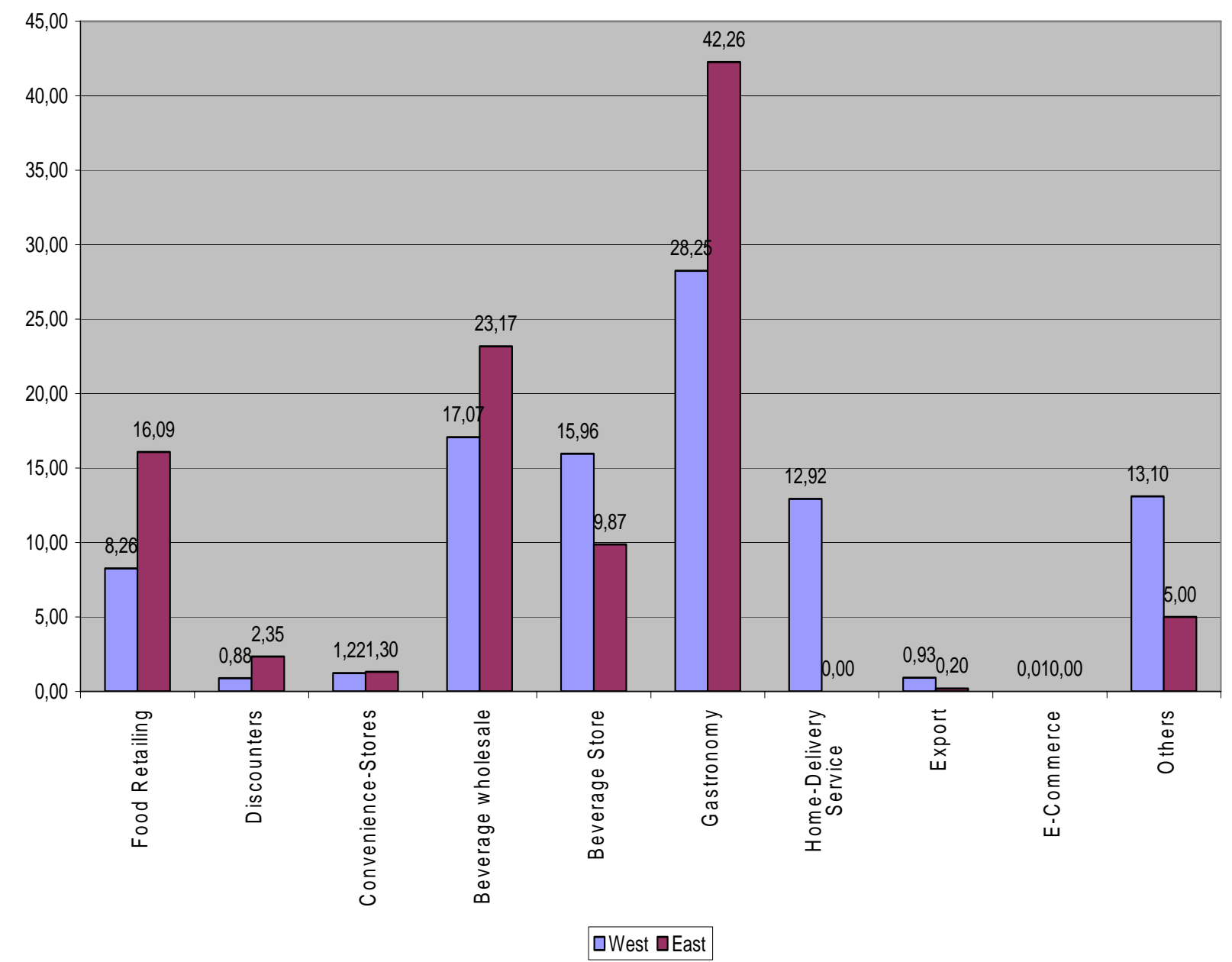


Compared to big foreign competitors, internationalization is of comparatively little interest to most German breweries. Nevertheless, about 22 percent of the breweries interviewed are active on the international market or plan to internationalize their activities in the near future. But the efforts to move into new markets and to enlarge the product-market spectrum differ with regard to firm size and region. Above all, larger breweries from Western Germany have already been internationalized.

Figure 4. Internationalization of the German brewing industry:

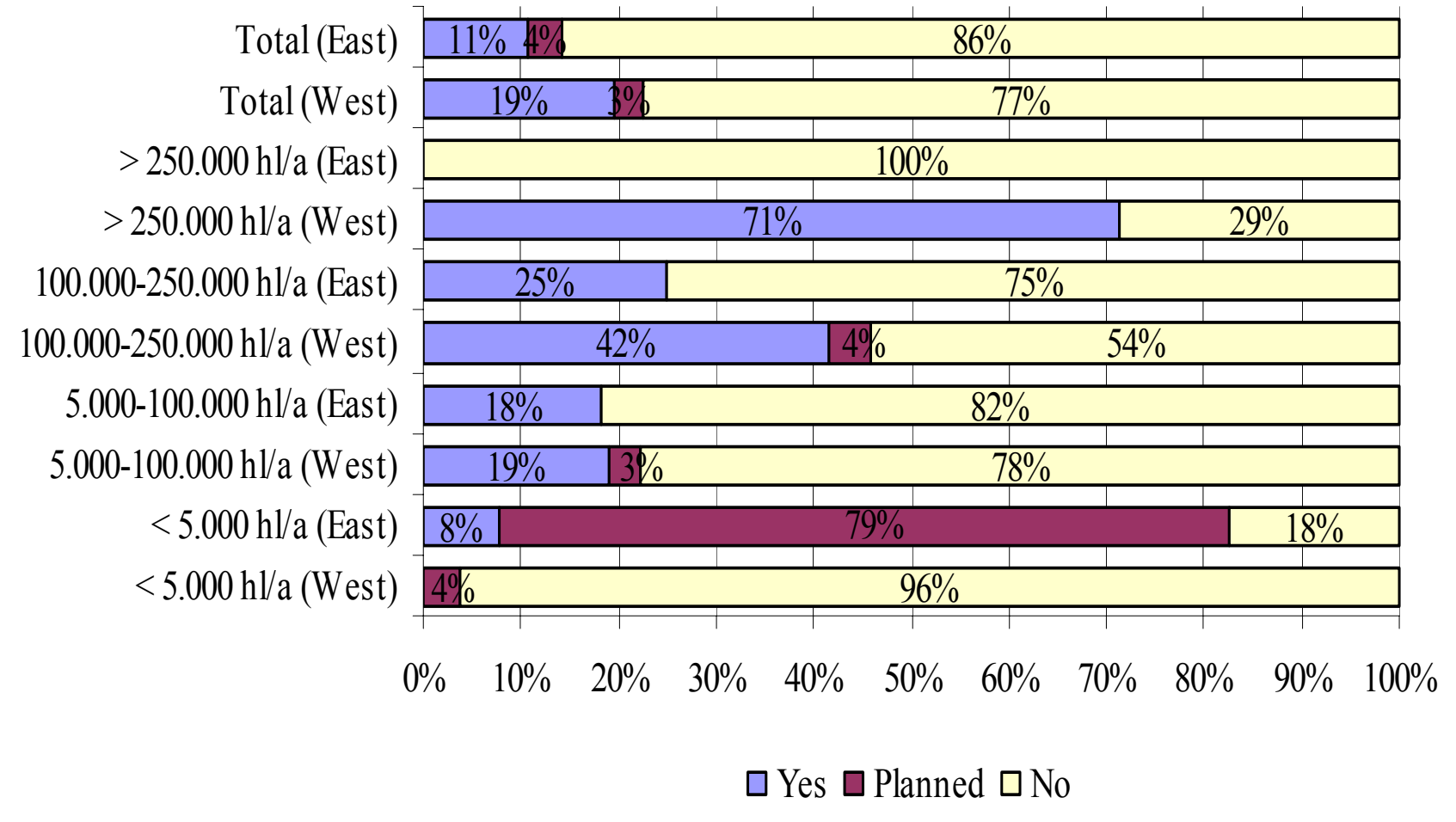

Meissner and Gerber (1990) distinguish between different forms of internationalization strategies such as exports, licensing, joint ventures, and fully-owned foreign subsidiaries depending on the amount of financial and managerial resources that have been transferred to non-domestic markets. 96 percent of the breweries surveyed serve international markets through exports. Only 13 percent of internationally active breweries have implemented licensing agreements, joint ventures, and other forms of internationalization. The percentage of foreign sales of all the breweries in the survey which are active on international markets is 6.3 percent.

About 18.6 percent of the breweries interviewed think that the importance of internationalization will increase in the future. This expectation is higher in Eastern (28 percent) than in Western (17.5 percent) Germany. This difference might be due to the currently very low degree of internationalization of Eastern 
German breweries. For many breweries, especially in Eastern Germany, exports might be a possible way to compensate for sales losses on their home markets.

Diversification is not only the most important element of a growth strategy based on developing new product-market combinations but also a form of risk spreading (Ansoff 1965). Horizontal, or lateral, diversification can be used by breweries to decrease their dependence on their main business - the difficult beer market. For the brewing sector, the distribution of non-alcoholic beverages is a traditional means of diversification that, due to its close relationship with the main business, is often employed (Theuvsen/Niederhut-Bollmann 2006). This strategy was chosen by about 55 percent of the enterprises participating in the survey. The expansion of the product-mix through non-alcoholic drinks correlates negatively $(-0.222)$ to brewery location in Eastern Germany with a significance at the 1 percent level. With regard to diversification, no other differences could be observed between Western and Eastern Germany.

\section{Competitive Strategies}

Brand management, price policy, and cost orientation are major elements of competitive strategies in the brewing industry.

With regard to the production of branded and no-name products, the majority (60 percent) of the breweries produce their own brands exclusively. There is no significant correlation between the percentage of branded products and the region. 
Figure 5. Percentage of branded products of total beverage output:

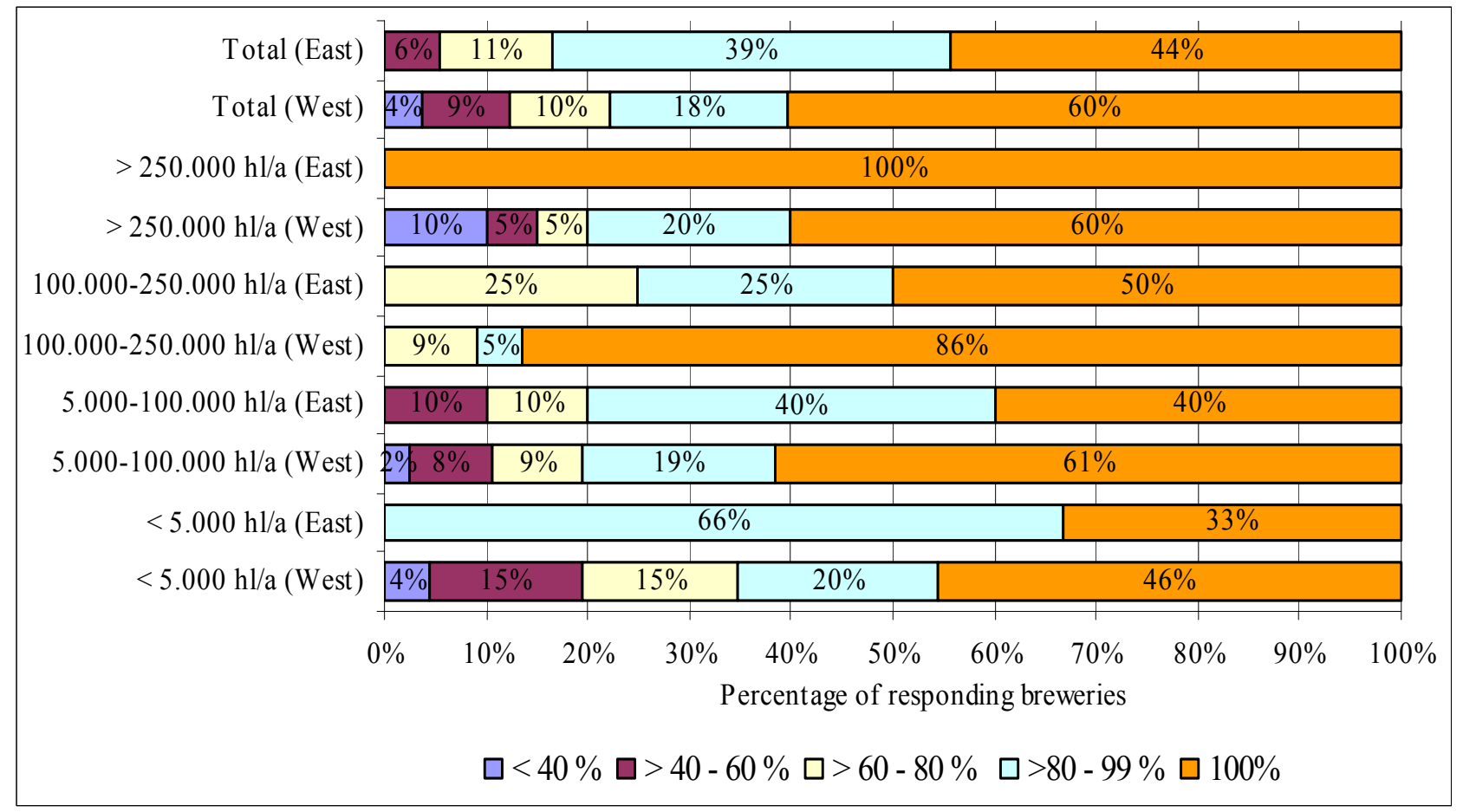

Instead, brewery size influences brand policy. Of the breweries with an annual output between 100,000 and 250,000 hl, 81 percent do not produce retailerowned trademarks. In our survey, none of the breweries of this size stated that they generate less than 60 percent of their total turnover through their own brands. In other size ranges, the percentage of breweries that produce mainly trademarks is significantly higher. One can assume that in these cases overcapacities are utilized by producing trademarks to maintain market shares and cover fixed costs.

With regard to price policy, the prices at the point of sale are most interesting. Pricing strategies are very different among Western and Eastern German breweries. As expected, beer is sold at much lower prices in the eastern part of Germany. Correlations between the regular prices of the main brand of breweries and region-Western or Eastern Germany-are significant at the 1 percent level for $20 \mathrm{x} 0.5\left(0.277^{* * *}\right)$ and the 5 percent level for $24 \mathrm{x} 0.33$ litre beer crates $\left(0.378^{* *}\right)$. 
Figure 6. Retail prices for the main beer brand (20x0.5 litre beer crates):

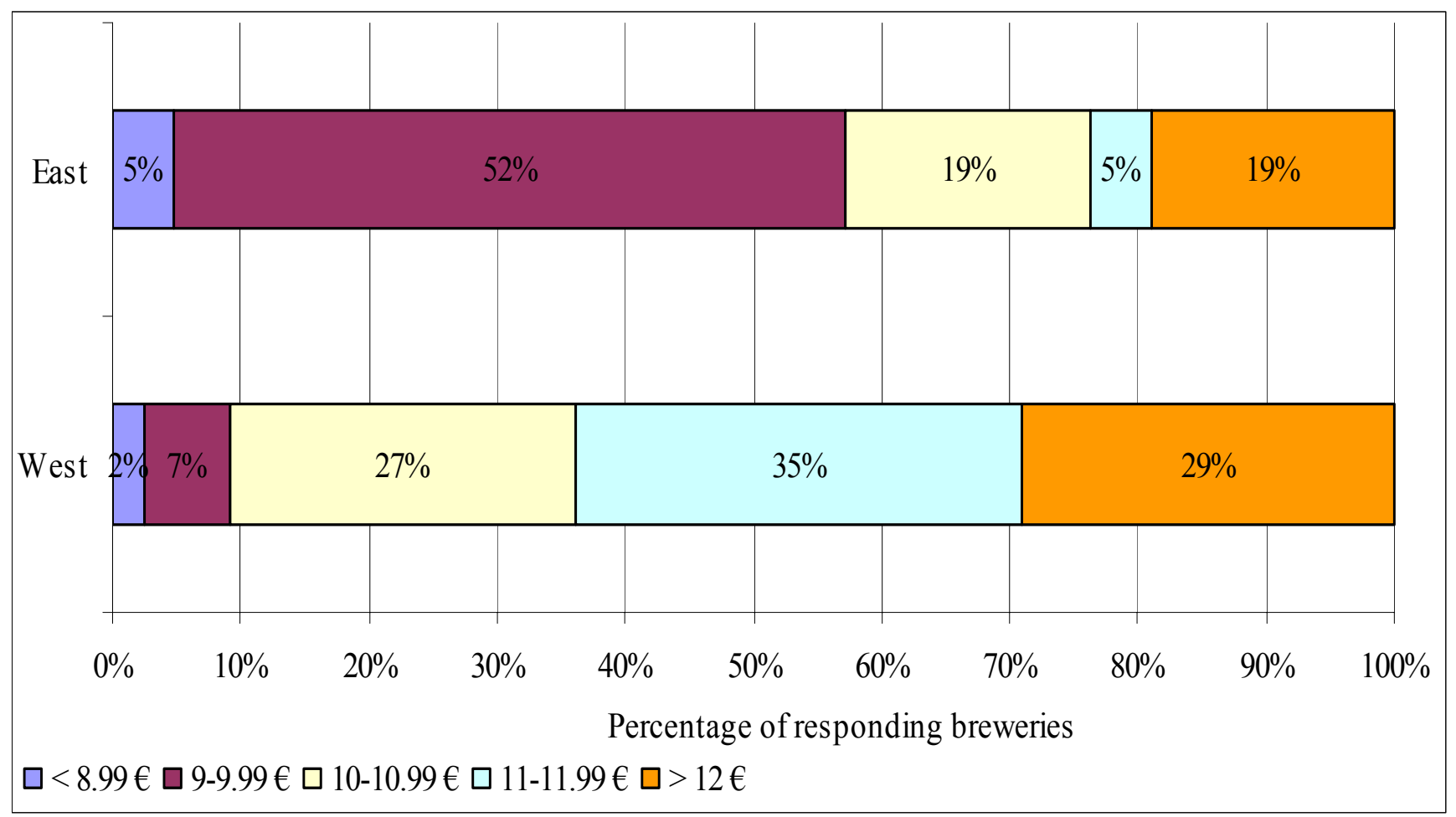

Figure 6 shows that more than half (57 percent) of the Eastern German breweries offer their main brand in $20 \times 0.5$ litre boxes at a price below $€ 10$, while Western German breweries in many cases serve the premium segment with their main brand and receive retail prices above $€ 11$.

As has already been mentioned, most breweries do not offer only one brand but also sub-brands which are usually less expensive. In this context, the different price strategies pursued in Western and Eastern Germany become even more apparent. Correlations between the regular prices of the sub-brands and region are $(0.301)$ for $20 \times 0.5$ (significant at the 1 percent level) and (0.21) for $24 \times 0.33$ litre crates. Most Eastern German breweries ( 82 percent) offer their sub-brands to customers in the low price segment at prices below $€ 10$, whilst their Western German counterparts retain their premium strategies for their sub-brands as well. 
Figure 7. Retail prices for breweries'sub-brands (20x0.5 litre beer crates):

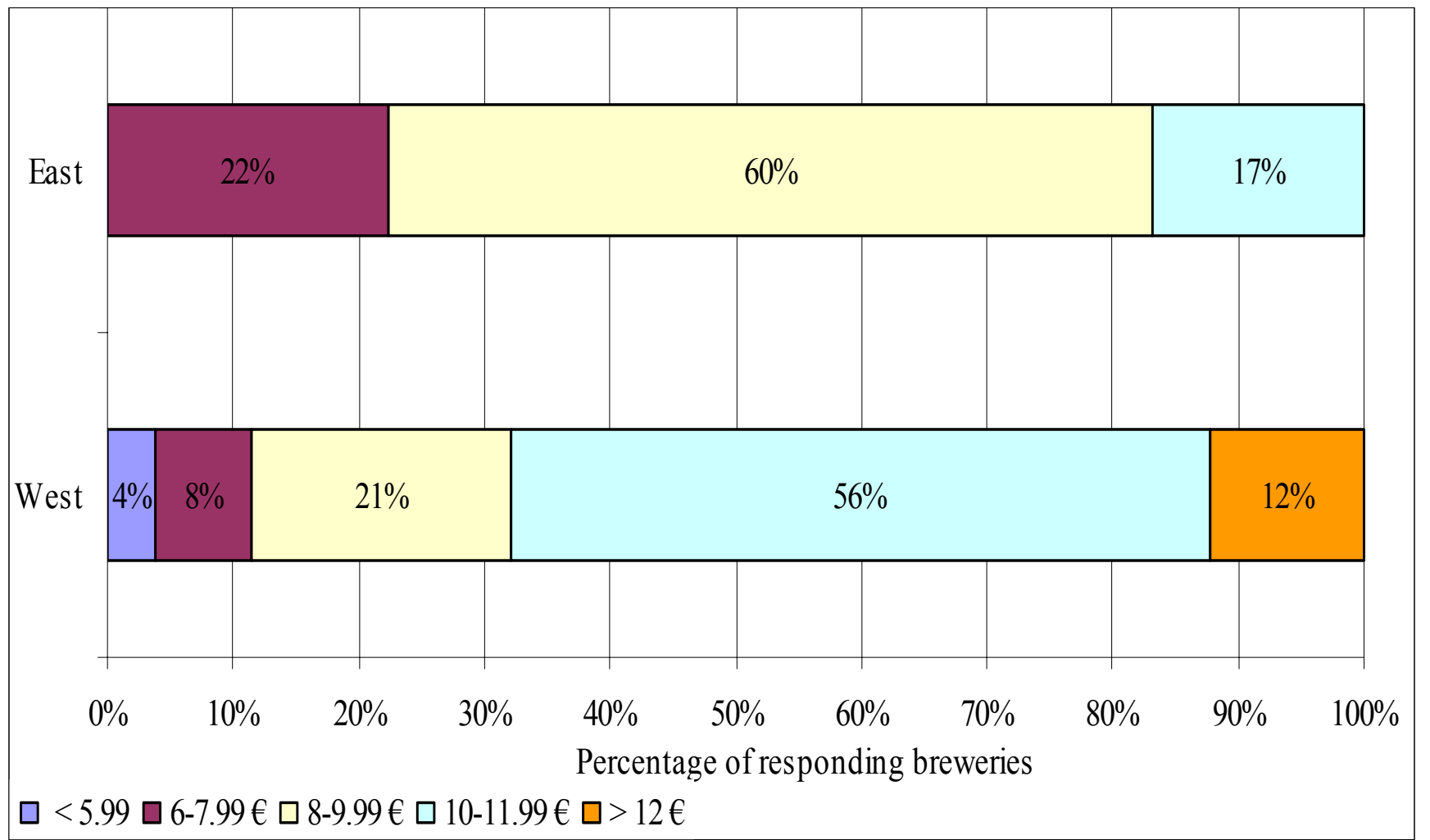

When comparing the retail prices with the costs of beer production, it becomes obvious that the latter differ between regions, too. Breweries in Western Germany achieve higher retail prices but, at the same time, also have higher production costs $(\mu=64.50 € ; \sigma=28.2)$ than breweries in Eastern Germany $(\mu=56.50 € ; \sigma=35.64)$; but since many breweries did not answer the question, this difference is not at a significant level. Therefore, the analysis of cost leadership strategies remains fragmentary.

The aim of a differentiation strategy is not cost leadership but gaining a unique selling proposition (USP) and inducing a higher willingness to pay and higher brand loyalty on the customers' part. In this context, it is paramount that consumers ascribe high-value attributes to the products of differentiating firms (Macharzina/Wolf 2005).

Hungenberg (2000) states that differentiation of homogeneous goods such as beer in most cases can be achieved only through brand building. The latter is part of a breweries' marketing activities. The marketing expenditures per hectolitre of beer are higher in Eastern Germany $(8.7 € / \mathrm{hl}[\sigma=6.4])$ than in Western Germany $(6 € / \mathrm{hl}[\sigma=5.4])$. But is the brand image of Eastern German breweries stronger as a result? In order to measure the brand image, we asked respondents to compare the brand images of their own products with those of their strongest competitors. As Figure 8 shows, Western German breweries have a more positive perception of the brand image of their beers than Eastern German breweries. More than 41 percent of the breweries in Eastern Germany 
think that they have a weaker brand image than their main competitor, whereas only about 27 percent of their Western German competitors attribute a weaker image to their products. A similar result is obtained with regard to the prestige of supplied gastronomy objects. The portion of Western German brewers (30 percent) who believe they deliver gastronomy objects with higher prestige and quality than their main competitors is twice as high as in Eastern Germany.

Figure 8. Brand image of brewery's own beer compared to the main competitor's:

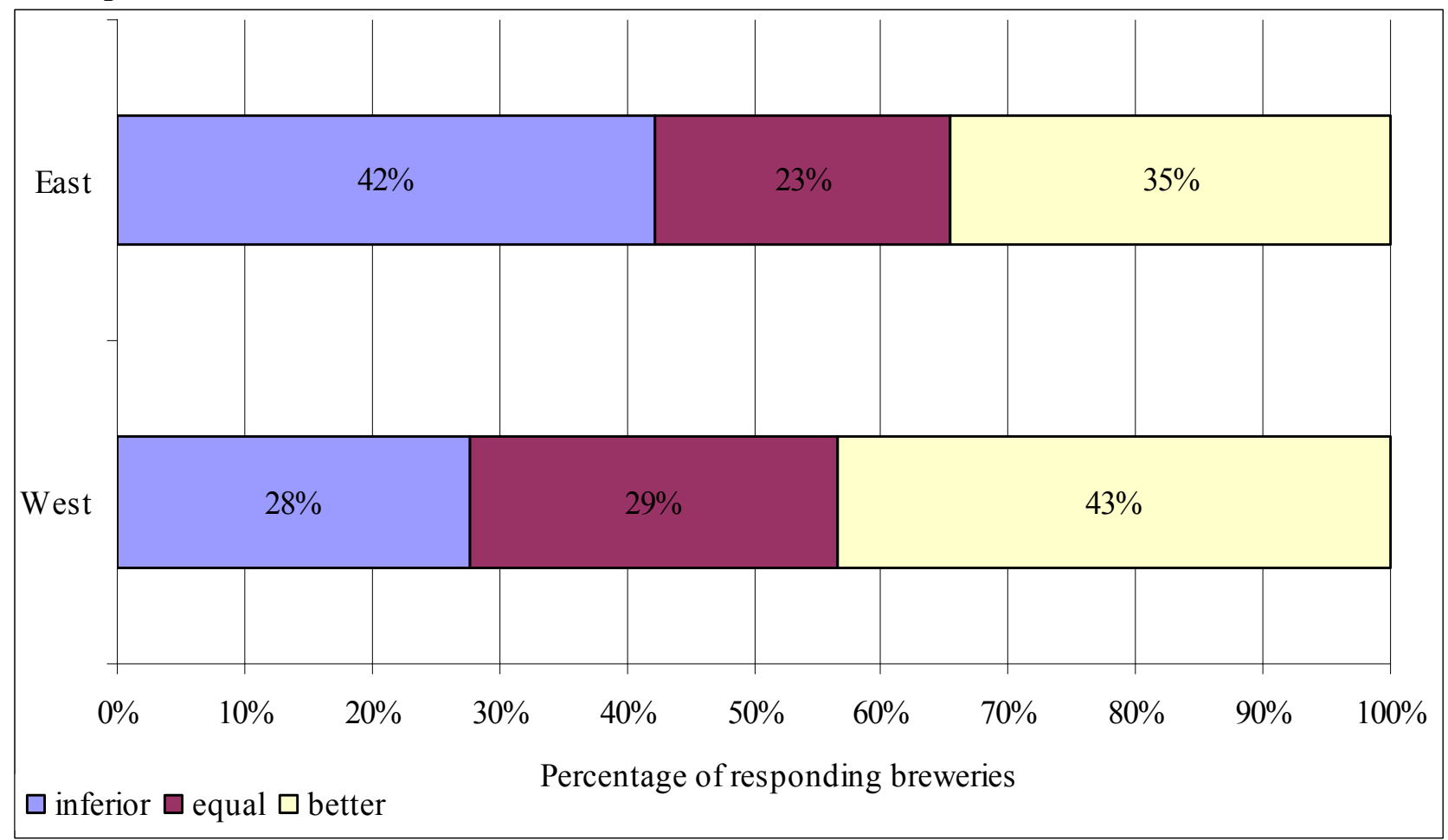

According to Macharzina and Wolf (2005), innovations are another way of implementing a differentiation strategy. Against the background of decreasing sales of classic products manufactured by the German brewing industry, innovations such as new beer mixes have gained a great deal of relevance in recent years. Enterprises that are the first to introduce innovative new products on the market often gain competitive advantages (Hungenberg 2000). A recent example of product innovation in the German brewing industry was the very successful launching of mild beers ("gold beers").

In the brewing industry, different innovation areas are available including beer mixes, mild beers, bottle forms and colours, crate sizes and design (NiederhutBollmann 2006). Significant differences between breweries in Western and Eastern Germany cannot be observed in this context. 


\subsubsection{Performance}

The success of breweries is often measured in hectolitres without taking profitability into account (Verstl 2005). In this paper we take a broader perspective and the performance of breweries is analysed by reference to changes in beverage output, turnover, profit, and ROI over the last three years. These changes are illustrated in Table 7. Obviously, breweries in Eastern Germany were able to increase their beverage outputs more strongly than Western German breweries. A higher percentage of breweries in Western Germany suffered declining turnovers, whereas almost every fifth brewery in Eastern Germany increased their turnover by more than 10 percent. A similar situation occurs with regard to profit changes over the last three years; again, breweries in Eastern Germany achieved higher increases. Only breweries' returns on investment do not differ remarkably between Western and Eastern Germany despite the higher profitability of Eastern German breweries.

Table 7. Changes in important performance indicators over the last three years:

\begin{tabular}{|c|c|c|c|c|c|c|c|c|}
\hline \multirow{2}{*}{$\begin{array}{l}\text { Performance } \\
\text { criterion } \\
\text { Region }\end{array}$} & \multicolumn{2}{|c|}{ Beverage output } & \multicolumn{2}{|c|}{ Turnover } & \multicolumn{2}{|c|}{ Profit } & \multicolumn{2}{|c|}{ ROI } \\
\hline & $\begin{array}{c}\text { West } \\
\mu=4.15 \\
\sigma=1.79\end{array}$ & $\begin{array}{c}\text { East } \\
\mu=4.86 \\
\sigma=1.69\end{array}$ & $\begin{array}{c}\text { West } \\
\mu=4.30 \\
\sigma=1.75\end{array}$ & $\begin{array}{c}\text { East } \\
\mu=4.68 \\
\sigma=1.72\end{array}$ & $\begin{array}{c}\text { West } \\
\mu=4.35 \\
\sigma=1.60\end{array}$ & $\begin{array}{c}\text { East } \\
\mu=4.64 \\
\sigma=1.49\end{array}$ & $\begin{array}{c}\text { West } \\
\mu=4.22 \\
\sigma=1.55\end{array}$ & $\begin{array}{c}\text { East } \\
\mu=4.15 \\
\sigma=1.56\end{array}$ \\
\hline $\begin{array}{l}\text { more than } 10 \\
\% \text { decline }(1)\end{array}$ & 9.6 & 3.6 & 8.7 & 4 & 6.3 & 0 & 5.2 & 10 \\
\hline $\begin{array}{l}5 \text { to } 10 \% \\
\text { decline }(2)\end{array}$ & 12.1 & 7.1 & 8.7 & 4 & 6.7 & 4 & 9.9 & 5 \\
\hline $\begin{array}{l}\text { decline up to } 5 \\
\% \text { (3) }\end{array}$ & 13.4 & 7.1 & 16 & 20 & 11 & 20 & 8.1 & 5 \\
\hline constant (4) & 18.8 & 25 & 15 & 20 & 33 & 32 & 43 & 45 \\
\hline $\begin{array}{l}\text { up to } 5 \% \\
\text { increase (5) }\end{array}$ & 20.1 & 17.9 & 25 & 16 & 19 & 12 & 13 & 15 \\
\hline $\begin{array}{l}\text { increase } \\
\text { between } 5 \text { to } \\
10 \%(6)\end{array}$ & 15.9 & 17.9 & 15 & 16 & 13 & 16 & 10 & 15 \\
\hline $\begin{array}{l}\text { more than } 10 \\
\% \text { increase }(7)\end{array}$ & 10 & 21.4 & 11 & 20 & 12 & 16 & 10 & 5 \\
\hline
\end{tabular}

Comparing the changes in beverage output and profits reveals that a lower percentage of breweries faced declining profits over the last three years than the percentage of breweries that suffered shrinking beverage sales. This indicates that higher prices and cost reductions in many cases more than compensated for shrinking sales volumes.

In addition to changes in beverage output and other performance indicators, the breweries were asked to assess their productivity compared to the average of the 
industry. About 30 percent of the breweries attribute to themselves a higher productivity, while 31 percent admit that their competitors were more productive. A greater percentage of brewers from Western Germany perceive themselves weaker in terms of productivity than their Eastern German counterparts (cf. Figure 9).

Figure 9. Perceived productivity of breweries compared to industry average:

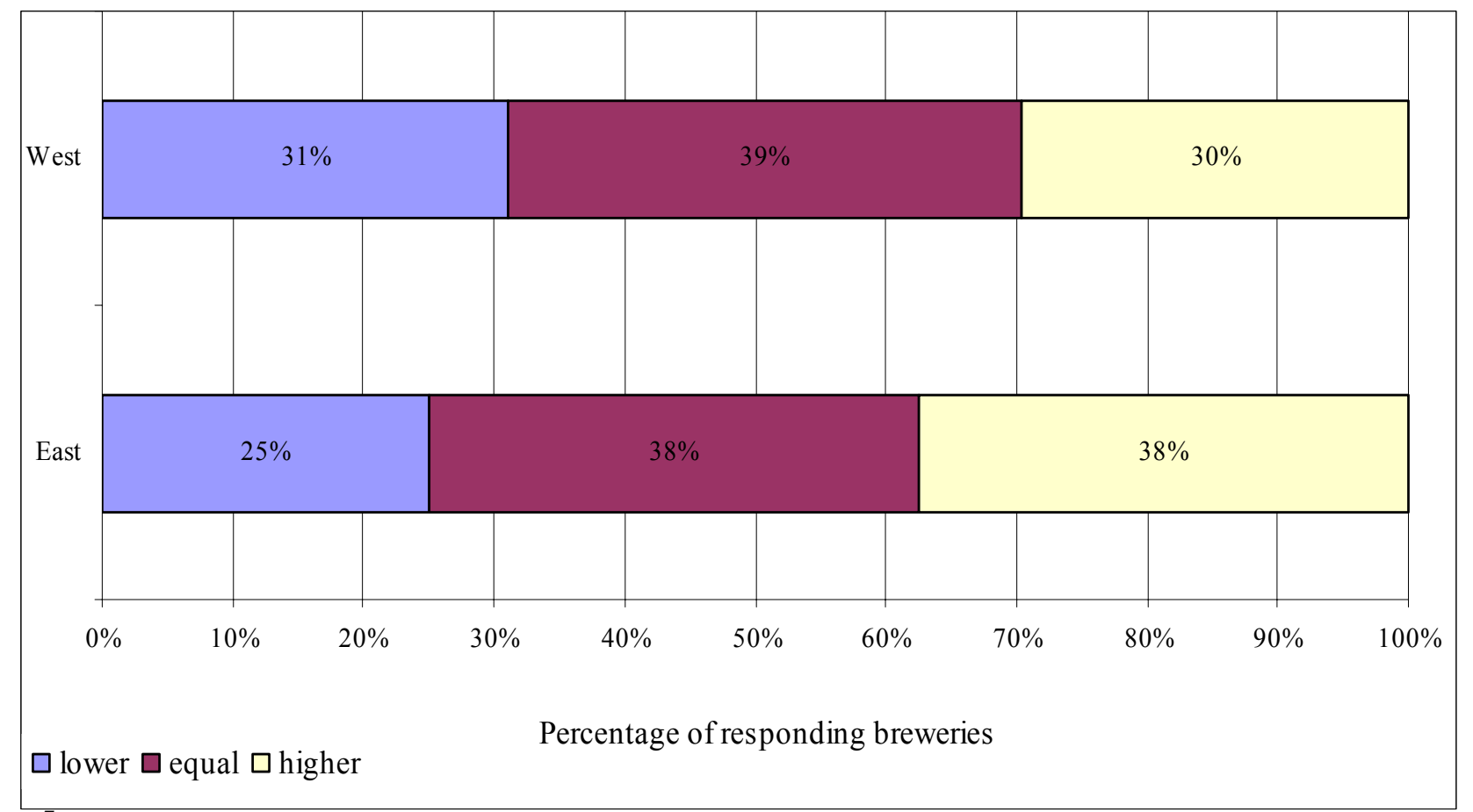

\subsection{Discussion of the Findings}

Günther and Gebhardt (2005) hypothesized that enterprises in Eastern and Western Germany differ significantly with regard to strategic management. Our empirical analysis of brewers' strategies in Western and Eastern Germany uncovered similarities as well as differences. Similarities could be observed with regard to the production of retailer-owned brands and innovations. The most striking differences exist with regard to product portfolio, degree of internationalization, distribution channels, diversification, perceived brand image, price policy, production costs, productivity, and performance. All in all, the number of differences is larger than the number of similarities with regard to strategic management in the Western and Eastern German brewing industries. In accordance with our theoretical framework, the remaining differences can be explained by different company environments such as regional consumer preferences and socioeconomic conditions.

Differing product portfolios are due to different regional consumer preferences. For instance, pilsner is the leading beer type in Eastern Germany, while lager and wheat beer are common mainly in Southern Germany (Bavaria, Baden- 
Württemberg) (Brunken 1990). Therefore, pilsner specialists have emerged in Eastern Germany, whereas the Southern German brewing scene has also produced lager and wheat beer specialists.

Other differences can be explained by different socio-economic environments, particularly lower incomes in Eastern Germany. Therefore, promoting premium brands and pursuing high-price strategies is more prevalent in Western Germany with many breweries even offering their sub-brands at comparatively high prices. In contrast, many Eastern German brewers offer not only their subbrands but also their main brands at comparatively low prices and in that way serve the more price-sensitive Eastern German mass market.

But the Eastern German brewing industry also shows how company strategies influence the competitive environment. Eastern German breweries are on the average larger than their Western German competitors (see table 3). This allows them to realize economies of scale and to take a cost leadership position. Furthermore, due to the high investments needed after reunification (Schwartau 1990), the production facilities of Eastern German breweries are comparatively new and, therefore, more productive and more cost efficient. Thus, structural changes in the industry, which have been much faster and more radical in Eastern Germany, now allow more price-oriented strategies and contribute to higher price pressures on the market, thus strongly influencing the breweries' external environment.

Nevertheless, the results also show convergence trends between strategic management in the East and the West. The perceived images of brands and gastronomy objects are currently weaker in Eastern Germany, and the scarcity of strong national brands in Eastern Germany is striking. But higher marketing expenditures in Eastern Germany indicate that Eastern German brewers have started a catch-up process.

Convergence will also be fostered by environmental changes. The exports of Western German brewers are mainly destined for Western markets such as the UK and the US. The Eastern German brewing industry does not serve those markets and, therefore, was characterized by a low export quota of only about 1.0 percent in 2006 (Federal Statistical Office 2006). Due to EU enlargement and the promising economic development of some of the Central and Eastern European countries, it can be expected that the importance of exports from Eastern German brewing facilities will grow in the future. These developments are supported in several Central und Eastern European countries "by fiscal policies implemented by governments to encourage a switch from high-alcohol content spirits to lower-alcohol content beers for health reasons" (Ebneth 2006: 68). For instance, the Russian beer market, which is by now the most important market for beer in Central and Eastern Europe, grew significantly with beer consumption almost tripling between the years 1998 and 2004 (Ebneth/Theuvsen 2006). As a result, differences in the degrees of 
internationalization between Western and Eastern German brewers will become less and less in the course of time.

Over the last few years, Eastern German breweries have been more successful than their Western German competitors. Many Eastern German brewers, for instance, increased their beverage outputs. Furthermore, a higher percentage of breweries in Western Germany suffered declining turnovers, whereas almost every fifth brewery in Eastern Germany increased its turnover by more than 10 percent. Subsequently, profits have also developed more favourably in Eastern Germany. These findings indicate that these companies have found sustainable strategic positions not despite, but due to, different strategies taking into consideration the peculiarities of the Eastern German market and their internal situation.

Of the 281 breweries surveyed, 92 can be classified as microbreweries with an annual output of less than 5,000 hl. The percentage of microbreweries - a growing trend in recent years in many countries (Bastian et al. 1999; Carroll/Swaminathan 2000; Anonymous 2007) - included in the study does not differ significantly between Eastern and Western Germany. Therefore, the observed differences and similarities between both regions are not influenced by the inclusion of microbreweries in the study.

The empirical findings obtained which show clear differences with regard to the regions under analysis are consistent with the theoretical framework developed taking into account the situation, strategy, and performance of the enterprises. Furthermore, the diagnosed differences between Eastern and Western Germany confirm Günther's and Gebhardt's (2005) aforementioned hypothesis that enterprises in both parts of Germany differ in terms of, for example, market orientation.

\section{Conclusions and future research}

The German beer market has been highly competitive for many years and, therefore, is in the midst of severe structural changes. In the long run, only breweries with the necessary financial and managerial resources will survive and stay on the market. In our paper some interesting similarities were identified as well as a considerable number of differences between Western and Eastern German breweries in terms of strategic management. All in all, Eastern German brewers seem to have some advantages compared to Western German beer producers with regard to such factors as size, cost per hectolitre, output, and sales growth and profitability. Due to the strong competition in the industry, the superior competitiveness of Eastern German breweries may allow them to outperform their Western German counterparts. Therefore, even larger parts of the German beer output, at least in the low-price segment, may move to Eastern German production facilities. 
In contrast, Western German breweries in the dataset currently own the comparatively stronger brands. Many fast moving consumer goods markets are characterized by hybrid consumers who tend to show multi-optional buying behaviour resulting in preferences for low-price as well as premium goods (Kunert 2006). Whereas Eastern German breweries seem to have the better strategic position for serving the low-price mass market, Western German brewers demonstrate competitive advantages in the premium segment. Whether higher marketing expenditures in the East will help to close this gap is still an open question. Thus, due to differences in strategic management, a bifurcation of the market may emerge with large mass producers in the East and smaller producers of premium brands and specialties in the West.

We believe that our findings are not restricted to the brewing sector but presume similar results for other fast moving consumer goods industries and commodity producers in Eastern Germany. In these sectors, the core production activities take place in a single region or in a singular location whereas the supply chains of technologically more differentiated products, e.g., automobiles, are much more complex and not restricted to a single country or region but by now characterized by global sourcing. This means that, in contrast to fast moving consumer goods, beer, for example, there is currently no car that is manufactured in Eastern Germany alone. Therefore, our findings can be considered representative for fast moving consumer goods but not for more complex products requiring different production and location strategies.

Future research should be directed at determining to what extent the brewing industry may serve as a role model or a cutting-edge industry for other subsectors of the food and beverage as well as other fast moving consumer goods industries. In other words, can the hypothesized bifurcation of the market resulting from strategic differences between East and West also be observed in other industries of this type?

Future research should also analyse in greater detail where and why differences exist between Eastern German and Western German food manufacturers with regard to strategic management. This would allow deeper insights into the role that contingency factors (Donaldson 2001), processes of institutionalization, mimetic behaviour (DiMaggio/Powell 1983), the availability of scarce and nonimitable resources (Leask/Parnell 2005), and path dependences (Miller 1993; Theuvsen 2004) may play for the emergence of similarities and the prevalence of differences in strategic management. In any case, the interrelations between structure, strategy, and the performance of enterprises, which have been a matter of interest of different scientific approaches for years (Wolf 2004), will remain in the focus of management and organizational research. 


\section{References}

Anonymous (2007): Wir machen ein völlig anderes Bier, in: Frankfurter Allgemeine Zeitung, 20 August 2007, 16.

Ansoff, H.I. (1965): Corporate strategy: An analytical approach to business policy for growth and expansion, New York: McGraw-Hill.

Bain, J.S. (1968): Industrial organization. $2^{\text {nd }}$ edition, New York: Wiley.

Bastian, C.T. et al (1999): Niche market potential: The case of the U.S. craft brewing industry, in: Review of Agricultural Economics, 21, 552-562.

Böbel, I. (1984): Wettbewerb und Industriekultur. Industrial-Organization-Forschung im Überblick. Berlin: Springer.

Breu, K. (2000): East German managers in transition: A study into individual change in transformative contexts. München, Mering: Hampp.

Brunken, A. (1990): Wettbewerbsstrategien in der mittelständischen Brauwirtschaft. Nürnberg: Hans Carl.

Bühler, S./Jaeger, F. (2002): Einführung in die Industrieökonomik. Berlin: Springer.

Bundesministerium für Verbraucherschutz, Ernährung und Landwirtschaft (BMVEL) (2005): Statistisches Jahrbuch über Ernährung, Landwirtschaft und Forsten der Bundesrepublik Deutschland 2005. Münster-Hiltrup: Landwirtschaftsverlag.

Bundesministerium für Ernährung, Landwirtschaft und Verbraucherschutz (BMELV) (2006): Ernährungswirtschaft in Ostdeutschland: Rahmenbedingungen, Strukturen, Wettbewerb. Tagungsdokument zur Zukunftskonferenz Ernährungswirtschaft, October 11-12, Magdeburg.

CaribouVerlag (2006): Website. http://www.wer-zu-wem.de/marken/Bier-Regional.html (23 November 2006).

Carrol, G.R./Swaminathan, A. (2000): Why the microbrewery movement? Organizational dynamics of resource partitioning in the U.S. brewing industry. Chicago: University of Chicago Press.

Chandler, A. (1962): Strategy and structure. Chapters in the history of the industrial enterprise, Cambridge, Mass.: M.I.T. Press.

Child, J. (1972): Organizational structure, environment and performance: The role of strategic choice, in: Sociology, 6, 1-22.

Clarke-Hill, C./Robinson, T. (1996): Acquisition experience of UK firms in the former East Germany, in: European Business Review, 96, 6, 30-40.

Deutsches Institut für Wirtschaftsforschung; Institut für Arbeitsmarkt und Berufsforschung; Institut für Weltwirtschaft an der Universität Kiel; Institut für Wirtschaftsforschung Halle; Zentrum für Europäische Wirtschaftsforschung (DIW Berlin/IAB/IfW/IWH/ZEW) (2003): Zweiter Fortschrittsbericht wirtschaftswissenschaftlicher Institute über die wirtschaftliche Entwicklung in Ostdeutschland (Second Progress Report by Economic Research Institutes about the Economic Development in East Germany). Special Editions 7/2003. Halle Institute for Economic Research, Halle. 
DiMaggio, P./Powell, W. (1983): The iron cage revisited: Institutional isomorphism and collective rationality in organizational fields, in: American Sociological Review, 48, 147-160.

Donaldson, L. (2001): The contingency theory of organizations. Thousand Oaks: Sage.

Drescher, K./Halm, S. (2005): Standortentscheidungen der Ernährungsindustrie in Ostdeutschland, in: Berichte über die Landwirtschaft, 82, 2, 287-300.

Dyck, A. (1997): Privatization in Eastern Germany: Management selection and economic transition, in: American Economic Review, 87, 4, 565-597.

Ebbertz, L. (1992): Die Konzentration im Braugewerbe der Bundesrepublik Deutschland. Frankfurt a. M.: Lang.

Ebers, M. (2004): Kontingenzansatz, in: Schreyögg, G./von Werder, A. (eds.): Handwörterbuch Unternehmensführung und Organisation. $4^{\text {th }}$ edition, Stuttgart: Poeschel, 654-679.

Ebneth, O. (2006): Internationalisierung und Unternehmenserfolg börsennotierter Braukonzerne. Ph.d. thesis, University of Göttingen.

Ebneth, O./Theuvsen, L. (2006): Five brewers pull the strings: Review of the Central \& Eastern European beer markets, in: Brewing and Beverage Industry International, 3, $10-14$.

Ebneth, O./Theuvsen, L. (2007): Large mergers and acquisitions of European brewing groups: Event study evidence on value creation, in: Agribusiness, 23, 3, 377-406.

Fombrun, C.J./Wally, S. (1989): Structuring small firms for rapid growth, in: Journal of Business Venturing, 4, 2, 107-122.

Frese, E. (1987): Unternehmungsführung, Landsberg a. Lech: Moderne Industrie.

German Brewers Association (2006a): Statistik-Daten und Fakten aus der Brauwirtschaft. www.brauerbund.de (21 September 2006).

German Brewers Association (2006b): Betriebene Braustätten nach Bundesländern. www.brauerbund.de (21 September 2006).

German Brewers Association (2006c): Der Markt: Die deutsche Brauwirtschaft in Zahlen. http://www.brauer-bund.de/index1.html (22 November 2006).

German Federal Statistical Office (2006): Beschäftigte und Umsatz des Produzierenden Ernährungsgewerbes nach Wirtschaftsklassen 2005. Wiesbaden.

Gergs, H.J. (2002): Manager und Märkte: Eine soziologische Analyse der Markterschließungslogiken des Managements ostdeutscher Industriebetriebe. München, Mehring: Hampp.

Günther, J./Gebhardt, O. (2005): Eastern Germany in the process of catching up, in: Eastern European Economics, 43, 3, 78-102.

Hay, D.A./Morris, D.J. (1979): Industrial economics: Theory and evidence. Oxford: Oxford University Press.

Hofer, C.W./Schendel, D. (1978): Strategy formulation: Analytical concepts. St. Paul: West Publishing Company. 
Hungenberg, H. (2000): Strategisches Management in Unternehmen: Ziele, Prozesse, Verfahren. Wiesbaden: Gabler.

Industrial Investment Council (2006): Food and beverages. http://www.iic.de/foodandbeverages.0.html (12 December 2006).

Industrial Investment Council (2005): Facts about eastern Germany. Productivity. http://www.iic.de/uploads/media/Productivity_in_Eastern_Germany.pdf December 2006).

Jaquemin, A. (1986): Industrieökonomik: Strategie und Effizienz des modernen Unternehmens. Frankfurt, New York: Campus.

Kahle, E. (1991): Europe 1992: Issues and implications, in: Calori, R./Lawrence P. (eds.): The business of Europe: Managing change. London et al.: Sage, 1-25.

Kieser, A. (2006): Der Situative Ansatz, in: Kieser, A./Ebers, M. (eds.): Organisationstheorien. $4^{\text {th }}$ edition. Stuttgart et al.: Kohlhammer, 215-245.

Kunert, M. (2006): Erfolgsfaktoren in mittelständischen Unternehmen der deutschen Brauindustrie. Nürnberg: Fachverlag Hans Carl.

Lawrence, P./Lorsch, J. (1967): Differentiation and integration in complex organizations, in: Administrative Science Quarterly, 12, 1-30.

Leask, G./Parnell, J.A. (2005): Integrating strategic groups and the resource based view: Understanding the competitive process, in: European Management Journal, 23, 458470 .

Lederer, V. (1998): Zur Transformation mittel- und osteuropäischer Betriebe: ein Vergleich ostdeutscher, polnischer und bulgarischer Betriebe auf qualitativ-empirischer Grundlage. Ph.d. thesis, University of Münster.

Lohr, K. (2003): Management und Managementprozesse in Ostdeutschland - Befunde und Perspektiven aus managementsoziologischer Sicht, in: Journal of East European Management Studies, 11, 4, 369-386.

Macharzina, K./Wolf, J. (2005): Unternehmensführung: Das internationale Managementwissen - Konzepte - Methoden - Praxis, $5^{\text {th }}$ edition, Wiesbaden: Gabler.

Marinov, M. (2002): Internationalization in Central and Eastern Europe. Aldershot: Ashgate.

Mason, E. (1949): The current state of the monopoly problem in the U.S. in: Harvard Law Review, 62, 1265-1285.

Meissner, H.G./Gerber, S. (1980): Die Auslandsinvestition als Entscheidungsproblem, in: Betriebswirtschaftliche Forschung und Praxis, 32, 217-228.

Miller, D. (1993): The architecture of simplicity, in: Academy of Management Review, 18, 116-138.

Niederhut-Bollmann, C. (2006): Strategische Gruppen in der deutschen Brauwirtschaft. Ph.d. thesis, University of Göttingen.

Pennings, J.M. (1981): Strategically interdependent organizations, in: Nystrom, P.D./Starbuck, W.H. (eds.): Handbook of Organizational Design. Oxford: University Press, IX-XXII.

Pfeffer, J./Salancik, G.R. (1978): The external control of organizations: A resource dependence perspective. New York: Harper \&Row. 
Pohlmann, M./Gergs, J. (1996): Manageriale Eliten im Transformationsprozess, in: Schmidt, R. (ed.): Beiträge zu den Berichten zum sozialen und politischen Wandel in Ostdeutschland. Opladen: Leske und Budrich, 63-98.

Porter, M.E. (1985): Competitive advantage: Creating and sustaining superior performance. New York, London: Free Press.

Scherer, F.M. (1985): Stand und Perspektiven der Industrieökonomik. In: Bombach, G. et al. (eds.): Industrieökonomik: Theorie und Empirie. Tübingen: Mohr (Siebeck), 3-9.

Schwartau, C. (1990): The East German food, drink and tobacco industries: Poorly equipped for the market economy, in: Economic Bulletin, 27, 8, 1-7.

Steele, M. (1992): The European brewing industry, in: Calori, R./Lawrence P. (eds.): The business of Europe: Managing change. London et al.: Sage, 26-71.

Steinhöfel, M. (1996): Personalstrategien und Unternehmenskulturen von Unternehmen in den neuen Bundesländern: Eine Diskussion empirischer Ergebnisse, in: Journal of East European Management Studies, 4, 2, 36-52.

Theuvsen, L. (2004): Pfadabhängigkeit als Forschungsprogramm für die Agrarökonomie, in: Agrarwirtschaft, 53, 111-122.

Theuvsen, L./Niederhut-Bollmann, C. (2004): Strategic management in turbulent markets: The case of the German brewing industry. In: Juracak, J. (ed.): Proceedings of the $2^{\text {nd }}$ HAED Conference: Management in Agribusiness, 4-5 November 2004, Zagreb (Croatia), 63-65.

Theuvsen, L./Niederhut-Bollmann, C. (2006): Perceived market risks and strategic risk management of food manufacturers: Empirical results from the German brewing industry. In: Fritz, M. et al. (eds.): Trust and risk in business networks. Bonn: ILBPress, 351-359.

Van de Ven, A.H./Drazin, R. (1985): The concept of fit in contingency theory, in: Cummings, L.L./Staw, B.M. (eds.): Research in organizational behavior, New York: JAI Press, 333-365.

Venkatraman, N. (1989): The concept of fit in strategy research: Toward verbal and statistical correspondence, in: Academy of Management Review, 14, 423-444.

Verstl, I. (2005): Die Sache mit den Zahlen, in: Brauwelt, 145, 7, 173.

Wheelen, T./Hunger, J.D. (2000): Strategic management and business policy. $7^{\text {th }}$ edition. Upper Saddle River, NJ: Prentice Hall.

Wolf, J. (2004): Strategie und organisationsstruktur, in: Schreyögg, G./von Werder, A. (eds.): Handwörterbuch Unternehmensführung und Organisation. $4^{\text {th }}$ edition, Stuttgart: Poeschel, 1374-1382. 